International Journal of Language Education

Volume 5, Number 4, 2021, pp. 244-259

ISSN: $2548-8457$ (Print) 2548-8465 (Online)

Doi: https://doi.org/10.26858/ijole.v5i4.19010

\title{
Students' Perception Toward Oral Corrective Feedback in Speaking Classes: A Case at English Education Department Students
}

\author{
Asnawi Muslem \\ Syiah Kuala University, Indonesia \\ Corresponding Email: drasnawi@unsyiah.ac.id \\ T. Zulfikar \\ AR-Raniry State Islamic University, Indonesia \\ Inas Astilla \\ Syiah Kuala University, Indonesia \\ Hendra Heriansyah \\ Syiah Kuala University, Indonesia
}

Saiful Marhaban

Syiah Kuala University, Indonesia

Received: 28 January 2021

Reviewed: 1 September 2021-31 November 2021

Accepted: 15 December 2021

\begin{abstract}
The objective of this study was to investigate students' perceptions towards oral corrective feedback from lecturers in their speaking classes. This survey involved 100 students of the English Language Education Department, Ar-Raniry State Islamic University (UIN Ar-Raniry) Banda Aceh from 254 students. The participants of the survey were selected using a simple random sampling technique to represent all of the population. A modified questionnaire from Calsiyao (2015, p. 397) and Elsaghayer (2014, p. 77) was used to collect the data. The interview was also used as the instrument of this study. This study used quantitative and qualitative methods in nature. The percentages were used to analyse the data collected from the questionnaires and qualitative method used to analyse the data from the interview. The results showed that the students perceived lecturers' oral corrective feedback as an important part of language learning. It was very helpful in improving the students' speaking abilities. It can be concluded that oral corrective feedback gave positive results to the students' speaking performances. Therefore, this study was significant to highlight the students' perceptions towards oral corrective feedback from their lecturers during the teaching and learning of speaking in their classes. Both lecturers and students would benefit from this research so that they can realise how important it is to give and accept oral corrective feedback.
\end{abstract}

Keywords: Lecturer; oral corrective feedback; Speaking Class; Students' Perception 


\section{Introduction}

Oral corrective feedback is an important issue that lecturers should take into account when teaching-learning speaking in the classroom at a university. This activity is often neglected by lecturers when students make mistakes and errors in their speaking classes. Agudo (2013, p. 265) has stated that "corrective feedback in classroom settings...[is] becoming a highly controversial issue, with arguments both for and against providing feedback". The ideal way is a lecturer should give oral corrective feedback if a student makes a mistake in speaking (Brown \& Rodgers, 2002; Rydahl, 2005; Kassa, 2011; Tomczyk, 2013). Conversely, teachers' oral corrective feedback can be embarrassing and destructive when it is used too frequently (Alqahtani and Al-enzi, 2011; Méndez and Cruz, 2012; Elsaghayer, 2014; Calsiyao, 2015). When the students think they have acquired sufficient target language and their errors last for a long time without teacher feedback, fossilisation of errors can occur (Alqahtani \& Al-enzi, 2011; Calsiyao, 2015; Ellis, 2009).

Khunaivi and Hartono (2015) have said that corrective feedback in speaking classes should be given in order to reduce the possibility of wrong target language use being continued leading to fossilisation of errors. In addition, Maolida (2013) has stated that a teacher's corrective feedback is important to promote "young learners' interlanguage development" (p.121). However, she points out that the teacher should deliver clear corrective feedback in order to ensure that the student truly understands the correct target language use. Solikhah (2016) has concluded that corrective feedback provided by a teacher can improve a student's speaking competence, though the teacher should not correct the student's errors while the student is speaking. In other words, the corrective feedback should not break the flow of the speech. On the whole, corrective feedback is very common in language classes. Yet, it is essential to be given wisely by teachers to avoid making students feel uneasy towards the corrective feedback.

Researchers have found the advantages of providing feedback for students. Feedback, whether in oral or written form, is viewed as a medium to improve the student's learning. Hussein \& Ali (2014), Kirgoz \& Agcam (2015), and Voerman, Meijer, Korthagen, and Simons (2012), agree that feedback is used to enhance language learning and make students aware of mistakes in the way they use the target language. In other words, feedback is given as a response to errors made by students when they are using the target language. This response shows that the student's use of the target language was not correct in some way, whether it was in pronunciation, grammar, collocation and or lexical items.

By contrast, others say that corrective feedback only causes setbacks in students' learning. According to Rahimi (2010:76) and Agudo (2012:123), corrective feedback should be avoided because it might be "harmful, time time-consuming ineffective." Moreover, Truscott (2007) agrees that corrective feedback is useless and harmful. In addition, 'overcorrection' towards the errors will damage the students' self-confidence because the students will be embarrassed when the teachers give feedback in front of others (Elsaghayer, 2014).

A non-native English student often produces errors in using the target language. However, those errors should be corrected wisely by her teacher. When those errors are over-corrected by the teacher, it could seriously affect that student's confidence, leading to anxiety (Arnold \& Brown, 1999). Therefore, teachers should know how and when feedback should be given. Otherwise, when teachers fail to do so, it can result in situations where the students choose to stay in 'defensive' mode (Agudo, 2013:266). Some students could possibly think that the feedback given by their teacher is too critical and cannot handle it (Alqahtani \& Al-enzi, 2011). When this situation happens, they can deny the feedback and put themselves on the defence. 
Not all the students' errors in using the target language should be corrected by the teachers. Errors that can interfere with the meaning of the communication should get a teacher's attention. Pronunciation is one type of error that can interfere with the meaning of the communication. Gitsaki and Althobaiti (2010) found that a beginner in target language learning can produce phonological errors frequently, and some of such errors can cause misunderstanding in communication. The time when error correction is given also needs to be considered. Teachers should never give it in the middle of a student's performance since this can disturb the student's focus. Martinez (2006) concludes that a teacher's interruptions during a student's performance can "break the flow of her speech", demoralise the student and "lower her motivation" (p.3). Therefore, this present study aimed at investigating the perception of students towards their lecturer's oral corrective feedback in speaking classes at Ar-Raniry State Islamic University, Banda Aceh. This study was different from the previous studies that had been done by researchers.

This current study focused on the lecturers' oral corrective feedback from students of the English education department. The focus is on the importance of error correction, agents who correct the error, preference of oral corrective feedback type, immediate feeling, students' reaction caused by immediate feedback, the timing of feedback, preference of the way of giving the feedback, kind of error to be corrected, and the impact of lecturers' oral corrective feedback. These kinds of oral corrective feedback are still limited discussed by researchers. Therefore, this current study is essential to investigate the reaction of students' feelings when they are given oral corrective feedback in the context of giving feedback during the teaching and learning process of speaking classes.

\section{Literature review}

Oral corrective feedback

For EFL students, making errors in using the target language is very common. Fidan (2015:1311) says that errors by an EFL student in using the target language are 'unavoidable'. In addition, Brown and Rodgers (2002) also state that almost all language learners produce errors in learning/using a new language. This is because English is not the first language that the students use in daily life. In addition, in the EFL context, they get very little exposure to the target language because it is only taught in school as part of the national curriculum, and there is minimal opportunity to use it in daily society. Even worse, they are not even given enough time to practice the target language in the classroom. Therefore, their teacher will be the primary source to correct any errors. Hedge (2000) claims that feedback or error correction from the teacher is needed when there is limited exposure to the target language. Brown (2001) asserts that students rely on the teacher in most EFL classes because they have very little feedback from their society.

Feedback, particularly corrective feedback, is one of the ways to improve a student's ability in using a target language. Gibbs and Simpson (2004) have claimed that feedback can:

Correct errors, develop understanding through explanations, generate more learning by suggesting further specific study tasks, promote the development of generic skills by focusing on evidence of the use of skills rather than on the content, promote meta-cognition by encouraging students' reflection and awareness of learning processes involved in the assignment and encourage students to continue studying (pp. 20-21).

In short, short corrective feedback is the best response to errors by a student in using her ESL. Corrective feedback is an indication that there are errors in a learner's use of the target language (Lightbown \& Spada, 1999). Corrective feedback can be seen as a helpful input for the 
student when given at an appropriate time. This means that the teachers should consider their students when giving them feedback. The majority of students who are corrected by an interruption in the middle of their speaking face the difficulty of continuing speaking and getting back with the flow of their ideas. Even worse, they can feel anxious, leading to speaking 'very cautiously' from then on. As a result, they will not then speak as fluently as they could usually do. Spiller (2009) has noted that:

Students may complain that feedback on assessment is unhelpful or unclear, and sometimes even demoralising. Additionally, students sometimes report that they are not given guidance as to how to use the feedback they get to improve subsequent performances. Even worse, students sometimes note that the feedback is provided too late to be of any use or relevance at all (p.2).

Furthermore, oral corrective feedback is oral feedback to correct a student's errors in using the target language, particularly student's spoken errors. Fungula (2013) has stated that oral corrective feedback is a direct indication or clue, when there is an error that a student has produced, of how to use the target language correctly. Annie (2011) said that oral corrective feedback is a teacher's verbal feedback in response to a student's error in a speaking performance and often focuses on pronunciation, vocabulary, collocation and language pattern, communication skills, ideas and organisation of the speech. In conclusion, oral corrective feedback is oral feedback given by a teacher or a peer to indicate an error in what a student said when using the target language.

Pros and cons of providing oral corrective feedback

As mentioned earlier, in the introduction for this paper, giving oral corrective feedback is still debatable amongst the experts. Many writers and researchers have spoken of the importance of providing oral corrective feedback in the language classroom (Ellis, 2009; Alqahtani and Alenzi, 2011; Voerman et al., 2012; Tomczyk, 2013; Maolida, 2013; Hussein and Ali, 2014; Kirgoz and Agcam, 2015; Calsiyao, 2015; Khunaivi and Hartono, 2015: Ur, 2006 ). Those writers believe that corrective feedback should be given in order to improve students' language learning. By providing oral corrective feedback, teachers can help the students minimise the possibility of committing the same errors in the future. Valero, Fernández, Iseni, and Clarkson, 2008; Rezaei, Mozaffari, and Hatef, 2011; and Amara, 2015) have argued that when a teacher ignores her student's errors in using the target language, over time, those errors become fossilised. Likewise, oral corrective feedback allows the students to notice the gap between the target language utterances they produce and how they should produce them (Rezaei et al., 2011; Jiang \& Yi, 2014). Thus, oral corrective feedback can promote the language development of the student.

Oral corrective feedback is not only perceived to have a positive effect but can also have a negative influence on language learners. Teachers can have a negative effect that can hinder a student's language development if it is given too much. Alqahtani and Al-enzi (2011:216) suggest that oral "corrective feedback can only be used to a limited extent, after which it can become discouraging and destructive." In addition, Arnold and Brown, 1999; Rahimi, 2010; \& Truscott, 2007) believe that oral corrective feedback can destroy students' self-confidence, demoralise the students and can be very harmful and even ineffective

Some consider oral corrective feedback can be worse than useless since, if their teacher gives the feedback at unpredictable times during the student's speaking performance, it might frighten them and make them stop speaking. Martinez (2006) has said that a teacher who gives 
error corrections that interrupts a student in the middle of her performance, especially in front of other students, can lower that student's motivation and hinder her language development. In addition, oral corrective feedback has a negative effect when a teacher carelessly gives feedback without considering the students' anxiety that might appear right after the feedback is given (Elsaghayer, 2014). When giving corrective feedback to a student, a teacher should consider the student's character and ability to benefit from such feedback (Khunaivi and Hartono, 2015; Muslem \& Abbas, 2017).

\section{Method}

Research design

This study used a combination of quantitative and qualitative research design, which focused on natural phenomena descriptions that occur naturally without manipulated circumstances. A survey was used to investigate the students' perception towards their teacher's oral corrective feedback in their speaking classes. McKay (2006, p.16) says "survey research is sandwiched between statistical experimental research and qualitative research...it can use both statistical and qualitative analysis." Mackey and Gass (2005), Mathers, Fox, and Hunn (2009) describe a survey study as a way of collecting information about the attitudes, characteristics, and opinions of a large group of people.

Population and sampling

The subjects of this research were students in the fourth semester at the English Department of the State Islamic University (SIU) Ar-Raniry, Banda Aceh: A sample of 131 was taken from 254 students with 25-30 students in each unit chosen. The students from the academic year 2014 were randomly chosen because they had passed all their speaking classes. Firstly, the authors randomly selected five units based on the suggested survey sample size of 131 with a $90 \%$ confidence level and a 5\% margin of error. Therefore, the authors were $90 \%$ confident that the samples represent the entire population within plus or minus $5 \%$.

Research instruments and validation

The study employed a set of questionnaires and interview to collect the data. The survey was done to get the answer to the research questions addressed to the students from the academic year 2014. A close-ended questionnaire was used as the instrument for this research to collect the students' perceptions of the oral corrective feedback their lecturers had given them in their speaking classes. The questionnaire used in this research was modified from those published by Calsiyao (2015) and Elsaghayer (2014). The questionnaire consisted of 13 items in the form of statements with four Likert scale alternative answers viz: strongly disagree, disagree, agree, and strongly agree. The authors used a semi-structured interview that was chosen because the authors might have to extend the questions based on the participants' responses. It was intended to get specific information from the students about their view of lecturers' oral corrective feedback. The additional questions in this interview have been composed based on questionnaire analysis to get deeper information about the students' perceptions.

\section{Data analysis}

To analyse the data collected, descriptive quantitative and qualitative were used. The data from the questionnaire were analysed quantitatively in the form of a percentage. Meanwhile, the 
data from interviews were analysed through descriptive qualitative. The data from the interview were analysed using the steps proposed by Miles and Huberman (1984, p.12). The steps include data reduction, data display, and drawing and verifying conclusions.

\section{Result and discussion}

The objective of the present study was to investigate the students' perception of their lecturers' oral corrective feedback at Ar-Raniry State Islamic University, Banda Aceh. The questionnaire includes thirteen statements related to lecturers' oral corrective feedback in speaking classes. Item number 1 and 2 covered a good influence of lecturers' corrective feedback, item number 4, 5, and 7 were related to students' feeling, items 3, 6, 10 discussed students' emotional reaction, as for kinds or types of errors to be corrected were discussed in item number $8,11,12$, and item number 9 and 13 were designed to know the perfect timing to provide oral corrective feedback. As for the chart, HAS stands for High Achieving Students, AAS stands for Average Achieving Students, LAS stands for Low Achieving Students. The researcher's interpretation of the questionnaire finding is presented below.

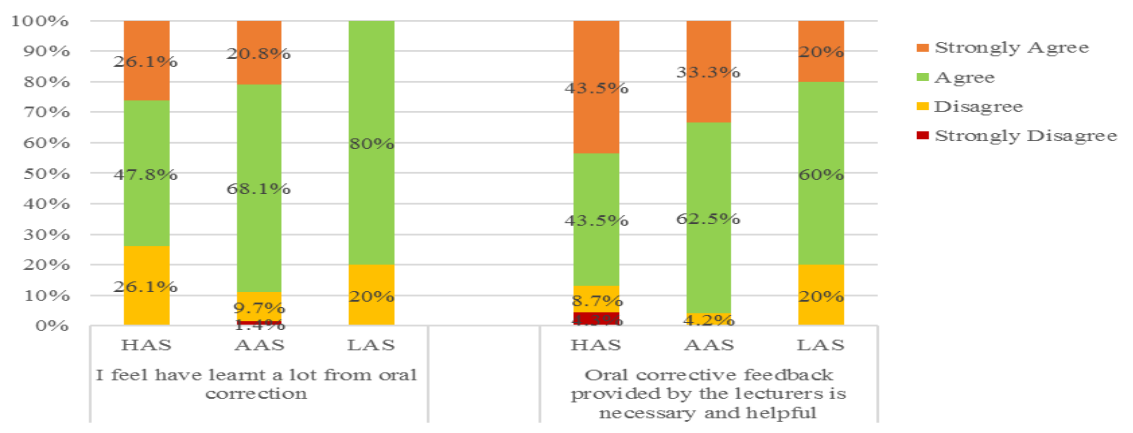

Chart 1: The perceived influence of lecturers' oral corrective feedback

Chart 1 shows the perceived influence of lecturers' oral corrective feedback. All students, either high, average, or low achieving students, agreed that they learn how to produce the correct utterance of the target language after receiving lecturers' oral corrective feedback. The majority of the students believe that error corrections or feedback in speaking classes were beneficial for learning English. Thus they learnt a lot from the feedback given. As we can see, high achieving students responded very positively towards the statement, with $26.1 \%$ strongly agreeing to the first statement and $43.5 \%$ of students strongly agreeing to the second statement. Contrariwise, only some of the students believed that oral corrective feedback provided by the lecturers was not necessary. Therefore, it can be concluded that according to the students, lecturers' oral corrective feedback is vital in learning a language, and it was helpful to improve their speaking skills.

Table 1. Students' Feelings after Receiving Lecturers' Oral Corrective Feedback

\begin{tabular}{|c|c|c|c|c|}
\hline \multirow[b]{2}{*}{ Statements } & \multicolumn{4}{|c|}{ Scale } \\
\hline & $\begin{array}{l}\text { Strongly } \\
\text { Disagree }\end{array}$ & Disagree & Agree & $\begin{array}{c}\text { Strongly } \\
\text { Agree }\end{array}$ \\
\hline
\end{tabular}


I worry about making errors in speaking class.

I hate oral errors because I start doubting myself.

I get upset when I do not understand what errors the lecturers is correcting.

$\begin{array}{llll}4 \% & 24 \% & 62 \% & 10 \% \\ 6 \% & 59 \% & 26 \% & 9 \% \\ 2 \% & 34 \% & 57 \% & 7 \%\end{array}$

Table 1 presents students' feelings after receiving lecturers' oral corrective feedback. About $72 \%$ of the students in the speaking classes claim that they were anxious about making spoken errors. Furthermore, in the same vein, $35 \%$ of the respondents were apprehensive about making errors because they usually start to doubt that they can speak English well. Moreover, they also got upset when they did not understand what their lecturer was correcting. This implies that the students want the lecturers to be very explicit when they are correcting errors so that they will understand what the errors were. When they know what the error was, they can understand the lecturers' feedback better. 64\% of the students got upset when they did not understand what their lecturer was correcting. Conversely, with the cumulative percentage of $36 \%$ who agreed and strongly agreed to the second statement about hating to make errors, students want their lecturers to point out their errors. Additionally, only about $28 \%$ of students did not worry that they would make errors while speaking in their speaking class, while the rest worried about making mistakes. However, $64 \%$ of the students did not hate making oral errors in speaking.

Table 2 Students' Emotional Reaction towards Oral Error and Feedback

\begin{tabular}{lcccc}
\hline \multirow{2}{*}{ Statements } & \multicolumn{4}{c}{ Scale } \\
\cline { 2 - 5 } & $\begin{array}{c}\text { Strongly } \\
\text { Disagree }\end{array}$ & Disagree & Agree & $\begin{array}{c}\text { Strongly } \\
\text { Agree }\end{array}$ \\
\hline $\begin{array}{l}\text { I resent it when I make an oral error. } \\
\begin{array}{l}\text { I resent being orally corrected by my lecturer in } \\
\text { the classroom. }\end{array}\end{array}$ & $15 \%$ & $38 \%$ & $41 \%$ & $6 \%$ \\
$\begin{array}{l}\text { I feel bad or angry when my lecturer corrects my } \\
\text { errors in front of my class. }\end{array}$ & $39 \%$ & $54 \%$ & $37 \%$ & $1 \%$ \\
\hline
\end{tabular}

Table 2 shows students' emotional reaction towards oral error and feedback. It reports that almost half of the respondents agreed that they resented making spoken errors during their speaking performances. Meanwhile, only 38\% resented it when the lecturer corrected their spoken errors, so it can be concluded that the students wanted to be corrected by the lecturers. In fact, only $7 \%$ of the students said that they did not feel bad or angry when their lecturers corrected their spoken errors. To sum up, oral corrective feedback from their lecturer did not have any negative impact because most students responded positively to being corrected. The students also did not resent it when they produced oral errors since this is very natural when learning a foreign language.

Table 3. Types of Error Corrected

\begin{tabular}{ccccc}
\hline \multirow{2}{*}{ Statements } & \multicolumn{3}{c}{ Scale } \\
\cline { 2 - 4 } & $\begin{array}{c}\text { Strongly } \\
\text { Disagree }\end{array}$ & Disagree & Agree & $\begin{array}{c}\text { Strongly } \\
\text { Agree }\end{array}$ \\
\hline
\end{tabular}


I am afraid that my lecturers will correct every error.

$\begin{array}{llll}16 \% & 58 \% & 23 \% & 3 \% \\ 5 \% & 17 \% & 57 \% & 21 \% \\ 4 \% & 41 \% & 45 \% & 10 \%\end{array}$

Lecturers should correct only those errors that interfere with the communication.

Table 3 displays the types of errors corrected. It shows that the students are concerned about how many errors will be corrected. The first statement shows that $74 \%$ of students were not afraid that their lecturers would correct every error they made. In the same vein, the second statement shows that $78 \%$ of the students want their speaking lecturers to correct every error they produced, while in the 3rd statement, $55 \%$ of students agreed that their lecturers should only focus on those errors that interfered with the communication. To sum up, although most students say they want all their oral errors to be corrected, only errors that can hinder communication should become the lecturers' priority. The lecturers should not correct every single error produced by their students.

Table 4. The Appropriate Timing of Giving the Feedback

\begin{tabular}{lcccc}
\hline \multicolumn{1}{c}{ Statements } & \multicolumn{4}{c}{ Scale } \\
\cline { 2 - 5 } & $\begin{array}{l}\text { Strongly } \\
\text { Disagree }\end{array}$ & Disagree & Agree & $\begin{array}{c}\text { Strongly } \\
\text { Agree }\end{array}$ \\
\hline $\begin{array}{l}\text { I feel anxious and do not know what to say after the } \\
\text { lecturers correct my errors. }\end{array}$ & $9 \%$ & $54 \%$ & $31 \%$ & $6 \%$ \\
$\begin{array}{l}\text { Lecturers should correct errors in the middle of the } \\
\text { conversation. }\end{array}$ & $14 \%$ & $64 \%$ & $18 \%$ & $4 \%$ \\
\hline
\end{tabular}

Table 4 shows the appropriate timing of giving feedback. It reports that $63 \%$ of the students disagreed with the first statement, which showed that they did not feel anxious after being corrected by the lecturers and could continue their performance. On the contrary, around $37 \%$ of the students felt anxious after the lecturers provided oral corrective feedback. Not surprisingly, $78 \%$ of the respondents were against the lecturers correcting their students' errors while they were speaking. In other words, to give feedback, the lecturers should wait until the students finish their speaking performance.

\section{High and low achieving students' perception towards lecturers' oral corrective feedback}

The interview was conducted with eight students in order to find their perception about the lecturers' oral corrective feedback in the classroom. In this phase, fifteen questions, including questions related to students' experience of learning English and their speaking achievement, were asked to eight interviewees. However, the researcher only focuses on nine main themes regarding lecturers' oral corrective feedback. The themes included: the importance of error correction, the agent who corrected the error, lecturers' oral corrective feedback, immediate feeling and emotional reaction, the timing of feedback, preference of feedback types, kind of error to be corrected and lecturers' oral corrective feedback impact.

The importance of error correction 
Students in this research believed that error correction is essential in speaking classes. Both high and low achieving students agreed that error correction helps them avoid producing the same error in the future. In other words, both high and low achievers take error correction to know the correct utterance to avoid fossilisation. A student with the highest speaking achievement asserted that error correction allows her to avoid repeating the same error in the next speaking performance. When the authors asked the question related to avoiding fossilisation, one of the respondents from high achievers believed that when the errors were abandoned entirely, she would not have known what the correct form was, and she would possibly repeat the same error in the future. She says "Of course it should be corrected. ... Because if we let someone produce the wrong utterance, I am certain that the error will last (forever) when the lecturer does not correct the error."

In terms of preventing the same error in the future, every single correction should be prevented to make the same error by students. She says "Because if the error is abandoned, it will evoke the same errors when performing speaking with particular or the same topic (in the future).... When the error is corrected, whether it will be corrected in the middle of speaking (performance) or at the end of the performance, the error correction will minimalise the same errors. "In addition, one participant from low achievers declared that feedback is very important to improve his speaking. Therefore, he will not repeat the same errors in the next performance. She says "It is absolutely important. ... Therefore, we could improve the errors in our speaking." Another respondent says that "Of course it (error correction) is important. Because when the feedback is given, we know (what and) where our error is, does not it? If there is no feedback, sometimes we...just only speak English and believe that we are using the language correctly. While in reality, it is not correct (there is an error). So, when the feedback is given, it will...become new information for us. We will not repeat the same errors." In the same vein, two respondents from low achievers thought the same as the high achievers. They said that they quickly noticed their error by having oral corrective feedback given by the lecturers. They agreed that lecturers need to correct the students during the speaking process they know the errors immediately. "I prefer to be corrected because when I was corrected during my performance, the correction let us know where our error was. 'It is essential to have feedback because feedback can help us to fix the error that occurred (in our speaking). Therefore, feedback can help us to produce a better sentence."

It can be concluded that both high and low achieving students agree that error correction is very important, especially in speaking class. It is due to the fact that feedback can help them to avoid repeating the same error in the future. In addition, it will also let them realise they have produced the wrong utterance, and as a result, the fossilisation will be minimalised. Lastly, they believe that error correction helps them to improve their speaking.

Agents who correct the error

During the interview, the authors found that each interviewee has their perception on who should correct their error. However, interestingly, they agree that teacher correction is the best way to correct the error. They asserted that the lecturers are the most responsible person to provide feedback. One of the respondents claims that she prefers self-correction because it enables her to be more alert when producing an error, and this way of error correction let her remember the error. However, she implicitly mentioned that the lecturer also gave feedback. The researcher classified it as a clarification request because the lecturer asked for clarification by simply saying "Are you sure?" She says "In my opinion, I myself (should correct the error). Because when the lecturer realised that I produced an error and say "Are you sure of what you are saying?" I will try to think "Which part of my utterances was wrong" until I realise "Oh, this is my error." In short, it (self- 
correction) will remind me that the word I produced was wrong." Another respondent from low achieving students also states that self-correction should come first. She says "In my opinion, selfcorrection. However, since we have very limited knowledge about the errors (in English) itself, therefore, lecturers should correct the error in the first place." When we asked further who should correct the students' error, one of the respondents claims that "actually, everyone can correct the error made by students of who involved in the teaching and learning process. She says "It is no problem to be corrected by the three agents (teacher, self, and peer). She believed that all the three agents could complement each other in teaching and learning. So, when she committed an error, and she did not realise, or when an agent was not paying attention, everyone in the class can become a person who corrected the error. She concluded her statement by mentioning that lecturers are more responsible than any other agents.

Lecturer oral corrective feedback

One of the students says, "Lecturers' oral corrective feedback is vital in speaking class." The lecturer can provide feedback and give more explanations on a particular topic that the students still struggle with. Lecturers' oral corrective feedback is very important in EFL classes because the students do not have enough exposure to the target language in their society. Therefore, lecturers' feedback is seen as the most accurate target language use.

(Student) 'If I get corrected by the lecturer, firstly, the error correction will be more accurate than the error I produced before. Then the lecturer' oral corrective feedback is correct, isn't it? If we correct our error by self-correction, the error is still possible to appear.'

(Student) 'It really depends. I like when the lecturer corrects my pronunciation, I really like it. Actually, I just like it. But it really depends on the way how the lecturer corrects my error."

(Student) "I like the lecturers' oral corrective feedback. In order to avoid the same error in the future."

(Student) 'It depends on the (way the lecturers give) feedback. If the feedback is given at an appropriate time.... it is really important. However, when it is not, I do not really favour it.

Preference of oral corrective feedback type

When we asked this question in the interview, a high achieving student insisted that she liked explicit correction and did not really like metalinguistic feedback. She compared that in correcting the students' error by explicit correction, the lecturers did not seem to patronise and overtly say what their students have done was wrong. They appreciate the students. However, in metalinguistic feedback, the lecturers made us feel unappreciated. She says "I really like explicit correction. Because, in my opinion, the lecturer does not impress patronising but only says "you should pronounce it this way." Not "Your pronunciation is wrong", the lecturer does not that harsh, only give explicit (correction). So, I like it very much." Another student claims that "I do not like metalinguistics feedback. ...Because, ...for example when we speak, the lecturer will correct our error by asking or presenting (metalinguistic feedback) the material (grammar error) about it. It looks like I do not understand the material at all. While in reality, I have already leant about it, and I know it. Maybe (when I perform) there is a slip of the tongue." A lower achiever also says that oral corrective feedback is essential. He says. "Explicit correction, I think....because it is to the point (directly point the error). However, here we can see that the lecturers try to manage the interaction with his or her students." 
When we asked students about the preference for clarification requests in giving feedback, one student from high achieving admitted that clarification requests were her favourite and she did not really favour recast. Clarification request enabled her to self-correct the error, she said. By giving this kind of error correction, the lecturers did not necessarily spoil their students by directly giving the correct answer. Instead, they give the students time to recall their memories. Thus, the learning can really take place. The student says "I like clarification request the most. Because, by this way (of correcting the error), I can find out which part of my utterances was produced wrongly. The lecturer only asks "Can you find your error? Therefore, because the lecturer corrects it that way (only ask for clarification), I can do self-correction by reflecting "Which one is my error?" "Why was it wrong?" She added that she did not really like recast because the lecturers directly provided the correct answer. It was very detrimental for the student who did not realise that they committed errors and might continue the same error repeatedly. "I do not like recast... because the lecturer is directly correct my wrong utterance (without giving time to do selfcorrection). Since the lecturer gave the correct utterance (recast), I just heard the error correction and realised, "Oh, this is my error". So, in the future, I might not realise I (possibly) commit the same error." So it can be concluded that each student has their own preferences about how they want to be corrected. Thus, Nunan $(1995$, p.140) noted that lecturers have to know "what their students think and feel about what and how they want to learn." (cited in Abedi, Mahdavi \& Hassaskhah, 2016, p.77).

Immediate feeling

When asking about the immediate feeling to the students after the lecturer gives them the corrective feedback, there are two kinds of feeling; positive and negative feeling. As the authors interviewed students, they were pleased when the lecturers gave oral corrections. They were glad because most of their lecturers only gave corrections after they finished speaking. However, they ever experienced that a few of their lecturers changed their facial expressions when they found the students' errors. They implicitly indicated that those lecturers did not seem to appreciate the students' effort. However, they would have a negative feeling when the lecturers give the feedback inappropriately. One of the students says that "As I said before, it depends on when and how the feedback is given. If it is given appropriately, I would love to receive it... but if it is not, sometimes, Ifeel uneasy."

Students' reaction caused by immediate feedback

In relation to this item, the students give positive and negative reaction when they are given immediate feedback. Students perceived feedback positively when the feedback was given at an appropriate time. Even though immediate feedback might distract their concentration, some students believe that they can obviously know what their error was. Thus, they can fix the error instantly after the immediate feedback. Inversely, students reacted negatively when immediate feedback caused nervousness or embarrassment. It can be concluded that lecturers can provide feedback in the middle or after the students' performance ends. However, it should be noted that the feedback should not distract students' concentration and embarrass the students in front of their friends.

The timing of feedback

Timing of giving feedback is essential to make the teaching and learning process in the classroom runs smoothly. One of the respondents says that she likes to be corrected at the end of 
her speaking. She adds, if the lecturers correct her while speaking, she will forget everything she wants to say. She says "I personally think it (the error) should be corrected right after I finish my speaking performance. So, exactly after the performance ends, the error should be explained. I do not really like it (to be corrected in the middle of my performance, before I finish speaking). Another respondent says that she likes to be corrected after some performances before the class ends. She reasoned that all students could learn something from each other's errors that the lecturers have already fixed. In addition, the students would not feel unappreciated and insulted before their peers. She claims "I prefer to be corrected after some performances (before the class ends). ...(like) Error analysis. So, the lecturer jots down all the students' errors, then (before the class ends) he or she states the error. Then it should be delivered for all students, not for one specific student. ...(because when the feedback is explained for the particular student)...he or she will feel uneasy. ... will think that the lecturer purposively points on him or her but not on the others. The rest (who were not being corrected) did a great work and only we who produced many errors. ... It will seem like (I) know nothing (about speaking). Thus, it is better to be given to all students. Generally.' Another respondent also says 'After I finish my performance. ... the feedback should be given. ...It should not be given in the middle of it (my performance). I do not like when my error is being corrected in the middle of my speaking performance. ...(because)...I will lose my idea. I cannot concentrate anymore."

Preference of the way of giving the feedback

In this case, students tend to be corrected with either explicit or implicit feedback. They have their own reason why they like to be corrected in such a way. One of the students claims "I prefer explicit feedback because implicit feedback forces me to think and I do not like to think (hard)....It is better if I know my error and the correction." Another respondent says "I prefer explicit feedback. ... So, I know where my error is...It will be easier to know the error and easier to remember the correct form (provided through feedback." On the other hand, students also like to have implicit feedback from their lecturers. One of the respondents says "Actually, I prefer implicit feedback. ...to avoid distracting our concentration. ...I like implicit feedback during the teaching and learning process. ...(because) share the knowledge for all students. ...(and) do not focus on specific students." Moreover, another respondent also wanted to be implicitly corrected because he did not want his friend to know his weakness and start to mock him for his error. "For me, both feedback (implicit and explicit) is okay. ...(but it depends on the lecturers themselves). ...(because) There are several lecturers, sometimes when their students produce an error, ask "Where did you learn previously?"...It lowers my self-confidence. ...(the lecturer) should not underestimate their student. (but by asking that questions) it seems like he or she underestimated us."

Kind of error to be corrected

When the authors asked the kind of error to be corrected, all respondents involved in the interview responded that they agreed to be corrected in the phonological error, especially in pronunciation. They believe that in English communication, mispronouncing the word can lead to misunderstanding. The most important thing in communication is that the interlocutor should understand what the speakers are talking about. Another kind of error to be corrected is Grammatical or Morphosyntactic Error. A low achiever respondent believed that it is important to pay attention more to grammatical errors. He stated that without correct grammar, his performance means nothing. He says "In my opinion, it is grammar is the most important aspect to be corrected 
because if there is a grammatical error, probably our pronunciation, vocabulary, or performance will also be disturbed." Besides, phonological error (pronunciation, accent, and intonation) is also important. A respondent compared phonological with grammatical error. She believed that a listener could possibly still understand what she was talking about even if she used the present tense to tell a past experience. However, when she pronounced a word in the wrong way, one might have understood it differently.

Impact of lecturers' oral corrective feedback

The authors found that students have different perceptions about the impact of lecturers' oral corrective feedback have on their speaking ability. Nevertheless, they indicated that the oral corrective feedback given by the lecturers improved their speaking. The respondents agreed that lecturers' oral corrected feedback could improve their speaking ability. They claim that having oral corrected feedback can increase the aspect of speaking skills, such as grammar, pronunciation, enabling them to speak more sequentially. Besides, it also improves students' confidence after having oral corrected feedback from the lecturers as one of the students says that "Firstly, we can minimise the error. Thus, we became more confident. In the future, we will not stutter anymore. When receiving feedback, we have to understand that we made errors and accept them. Then we have to fix it. The feedback will become new information so that we would not repeat the same errors in the future." In conclusion, lecturers' oral corrective feedbacks have various impact on students' speaking ability. Students' confidence, pronunciation, and way of presenting were getting better after the feedback was given. Moreover, the students seem to be more prepared before they perform in the next meeting because they do not want to repeat the same error. As Tomczyk (2013) wrote, to make progress in students' learning, the teacher should make their students aware of their erroneous because it fosters them to avoid the same error in the future.

In learning a language, the presence of corrective feedback from the lecturers is essential. However, the way teachers or lecturers give corrective feedback is also important to avoid embarrassment for students (Maolida, 2013). This current study reported that oral corrective feedback from the teachers or lecturers during the teaching and learning process was beneficial for students. By having corrective from lecturers, they could improve their competence especially speaking skills. For example, "Yesterday I go to Medan with my parent" This sentence could be understood by the listener. However, it was grammatically incorrect. So, lecturers could correct directly by saying "Oh, you went to Medang yesterday with your parents". So, this way of correcting students' mistakes was safe and soft. Teachers or lecturers should also consider the students' characteristics to avoid them losing face when given corrective feedback. Feedback gives positive impact towards students' speaking development (Hussein \& Ali, 2014; Kirgoz \& Agcam, 2015; Ellis, 2006; Ellis, 2009; Alqahtani \&Al-enzi, 2011; Voerman et al., 2012; Tomczyk, 2013; Maolida, 2013; Calsiyao, 2015; Khunaivi \& Hartono, 2015; Solikhah, 2016). Analysis of the findings showed that most of the students agreed with their lecturers giving oral corrective feedback. This is in line with other previous studies like (Hussein \& Ali, 2014; Kirgoz \& Agcam, 2015). However, many students also felt that they felt anxious when lecturers gave them oral corrective feedback. Spiller (2009), Cruz (2012) Elsaghayer (2014) and Calsiyao (2015) declare that over-correction of students' errors can increase students' anxiety and decrease students' selfconfidence. This current study is also in line with the research finding that conducted by Guibangguibang (2020). It was found out that the frequency of explicit correction, recast, and repetition, as perceived by ESL major students of their English teachers' oral error correction types, have no significant relationships to their English language anxiety (Guibangguibang (2020). 


\section{Conclusions}

In general, most students like to receive' oral corrective feedback from their lecturer. The questionnaire analysis found that the students believed that feedback provided by their lecturer was valuable and made them learn something. The students showed almost the same feeling about the possibility of making spoken errors. Most students worried they might produce oral errors, but they did not dislike it when they produced oral errors. However, most of them got upset when they did not understand what their lecturer was correcting. Therefore, lecturers have to deliver clear oral feedback. It can be concluded that students perceived lecturers oral corrective feedback as an essential part of language learning because they learnt how to use the correct form of the target language after being corrected.

From the survey results, suggestions for speaking lecturers and students and future researchers are drawn that since the students perceived oral corrective feedback helpful and very important in language classes, the lecturers should provide oral corrective feedback whenever they note that a student commits an error. This is intended to enable the students to become aware of their errors and avoid repeating them. Another benefit is that oral corrective feedback can avoid the fossilisation of errors occurring in spoken language. Further studies should also be done, possibly using experimental research design to measure the benefits of giving positive feedback and to compare the results of giving positive feedback with that of giving negative feedback or a combination of both positive and negative feedback.

Declaration of conflicting interest

The authors declare that there is no conflict of interest in this work.

Funding acknowledgement

The authors received no specific funding for this work.

\section{References}

Agudo, J. D. M. (2013). An investigation into how EFL learners emotionally respond to teachers' oral corrective feedback. Colombia Applied Linguist Journal, 15(2), 265 - 278. , (2012). Investigating Spanish EFL students' beliefs and preferences regarding the effectiveness of corrective feedback. International Journal of Humanities and Social Science, 2(19), $121-131$.

Alqahtani, A. A., \& Al-enzi, E. K. (2011). EFL teachers' feedback to oral errors in an EFL classroom: Teachers' perspectives. Arab World English Journal, 2(1), 214-232.

Amara, N. (2015). Error correction in foreign language teaching. The Online Journal of New Horizons in Education, 5(3): 58-68.

Annie, T. (2011). Exploring Students' Perception of and Reactions to Feedback in School-Based Assessment. Malaysian Journal of ELT Research, 7(2), 107-127.

Arnold, J.(Ed.), (1999). Affect in Language Learning (pp. 1-24, Arnold,J., \& Brown, H. D. (1999). A Map of the Terrain). Cambridge: Cambridge University Press.

Brown, H. D. (2001). Teaching by Principles: An Interactive Approach to Language Pedagogy. (Third Edition). San Fransisco: Longman.

Brown, J. D., \& Rodgers, T. S. (2002). Doing Second Language Research. New York: Oxford University Press. 
Calsiyao, I. S. (2015). Corrective feedback in classroom oral errors among Kalinga-Apayao state college students. International Journal of Science and Humanities Research, 3(1), 394-400.

Cruz (2012) see p 8Ellis, R. (2009). Corrective feedback and teacher development. L2 Journal, $1(1), 3-18$.

, (2006). Researching the Effects of Form-focused Instruction on L2 Acquisition. AILA Review, 19, 18-41.

Elsaghayer, M. (2014). Affective Damage to oral corrective feedback among students in Libyan secondary schools. IOSR Journal of Research \& Method in Education (IOSR-JRME), 4(6), $74-82$.

Fidan, D. (2015). Learners' preferences of oral corrective feedback: An example of Turkish as a foreign language learners. Educational Research and Reviews, 10(9), 1311-1317.

Fungula, B. N. (2013). Oral Corrective Feedback in the Chinese EFL Classroom. (Degree Project). Karlstads Universitet. Retrieved on November 6, 2015 from http://www.divaportal.org/smash/get/diva2:693017/FULLTEXT01.pdf.

Gibbs, G., \& Simpson, C. (2004). Conditions under which assessment supports students' learning. Learning in Teaching in Higher Education, 1(1), 3-31.

Gitsaki, C., \& Althobaiti, N. (2010). ESL teachers' use of corrective feedback and its effect on learners' uptake. The Journal of Asia TEFL. 7(1), 197-219.

Guibangguibang, H. R. B. (2020). Association between Oral Error Corrections of University Teacher and English Majors' Language Anxiety in Philippine Higher Education Context. International Journal of Language Education, 4 (2), 183-193.

Hedge, T. (2000). Teaching and Learning in The Language Classroom. Oxford Handbook for Language Teachers Series. Oxford: Oxford University Press.

Hussein, B. A. E., \& Ali, H. I. H. (2014). Rationalising oral corrective feedback in Sudanese EFL classrooms. International Journal of Applied Linguistics \& English Literature, 3(3), 217-231.

Jiang, L., \& Yi, H. (2014). The effect of positive evidence and negative feedback on EFL learners' acquisition of the third person singular form. International Journal of English Linguistics, $4(6), 124-133$.

Kassa, A. A. (2011). Oral Corrective Feedback: An Exploratory Case Study Of The Interplay Between Teachers'Beliefs, Classroom Practices, And Rationales. (Unpublished Dissertation). Ethiopia, Addis Ababa University,

Khunaivi, H., \& Hartono, R. (2015). Teacher's and Student's Perceptions Of Corrective Feedback In Teaching Speaking. English Education Journal, 5(2), 14-20.

Kirgoz \& Agcam (2015) see p 8Lightbown, P. M., \& Spada, N. (1999). How Languages Are Learned. Revised Edition. Oxford: University Press.

Maolida, E. H. (2013). A Descriptive Study Of Teacher's Oral Corrective Feedback In An ESL Young Learner Classroom In Indonesia. $k @ t a, 15(2), 117-124$.

Martínez, S. G. (2006). Should We Correct Our Students' Errors In L2 Learning? Encuentro, 16, 17.

Méndez, E.H. \& Cruz, M.R.R., (2012). Teachers' perceptions about oral corrective feedback and their practice in EFL classrooms. PROFILE, 14(2), 63-75.

Muslem, A., \& Abbas, M. (2017). The effectiveness of immersive multimedia learning with peer support on English speaking and reading aloud. International Journal of Instruction, 10(1), 203-218 
Rahimi, M. (2010). Iranian EFL students' perception and preferences for teachers' written feedback: Do students' ideas reflect teachers' practice? The Journal of Teaching Language Skills (JTLS), 2(2), $75-98$.

Rezaei, S., Mozaffari, F., \& Hatef, A. (2011). Corrective Feedback in SLA: Classroom Practice \& Future Directions. International Journal of English Linguistics, 1(1), 21-29.

Rydahl, S. (2005). Oral Feedback in the English Classroom: Teachers' Thoughts And Awareness. Karlstads Universitet. Retrieved February 3, 2016 from www.divaportal.org/smash/get/diva2:6576/FULLTEXT01.pdf.

Solikhah, I. (2016). Oral Corrective Feedback In Speaking Class Of English Department. Lingua, 13(1), 87-102.

Spiller, D. (2009). Assessment: Feedback to Promote Student Learning. The University of Waikato, 1-19. Retrieved from http://www.waikato.ac.nz/tdu/pdf/6 AssessmentFeedback.pdf.

Tomczyk, E. (2013). Perception of Oral Errors And Their Corrective Feedback: Teachers Vs. Students. Journal of Language Teaching and Research, 4(5), 924-931.

Truscott, J. (2007). The Effect Of Error Correction On Learners' Ability To Write Accurately. Journal of Second Language Writing, 16, 255-272.

Ur, P. (2006). A Course In Language Teaching: Practice And Theory. Cambridge: Cambridge University Press. 